\title{
ANALISIS PERTIMBANGAN HAKIM DALAM PERALIHAN HAK ATAS TANAH TERLANTAR MILIK BADAN USAHA MILIK NEGARA NOMOR : 03/PDT.G/2011/PN-LSM"
}

\author{
${ }^{1}$ Nurmalinda, ${ }^{2}$ Sulaiman, ${ }^{2}$ Herinawati \\ Co. author : herinawati@unimal.ac.id \\ ${ }^{1}$ Mahasiswa Fakultas Hukum Universitas Malikussaleh \\ ${ }^{2}$ Dosen Fakultas Hukum Unimal
}

\begin{abstract}
Abandoned land is land that has been granted rights by the state in the form of Ownership Rights, Business Utilization Rights, Building Use Rights, Use Rights and Management Rights, or basic control over land that is not cultivated, not used, or not utilized in accordance with the circumstances or the nature and purpose. granting rights or the basis for their control. The definition of abandoned land is not regulated in Government Regulation of the Republic of Indonesia Number 11 of 2010 concerning Control and Utilization of Abandoned Land ("PP No. 11/2010"). However, it is regulated in Article 1 point 6 of the Regulation of the Head of the National Land Agency of the Republic of Indonesia Number 4 of 2010 concerning Procedures for Controlling Abandoned Land.The results of the study explain that the judge with his considerations in the case related to the transfer of rights to abandoned land belonging to state-owned enterprises in the decision Number: 3/Pdt.G/2011/PN-Lsm The judge considered that the problem in the abandoned domain was absolutely not the authority of the lhokseumawe district court. However, in the State Administrative Court, because the plaintiff in his case mentioned the ownership assets of the land. Thus, the judge rejected all of the plaintiffs' claims.
\end{abstract}




\section{Pendahuluan}

Tanah merupakan suatu anugerah dari Tuhan Yang Maha Esa bagi manusia khususnya rakyat, bangsa dan negara Indonesia, kerena pada hakikatnya tanah merupakan sumber dari segala aktivitas siapapun yang berada di atasnya. Tanah harus diusahakan, dimanfaatkan dan dipergunakan untuk sebesar-besarnya kemakmuran rakyat dan bangsa Indonesia hal ini adalah amanat dari Pasal 33 Ayat (3) UndangUndang Dasar Negara Republik Indonesia 1945 ( UUD 1945 ) yang berbunyi "Bumi, Air, dan kekayaan alam yang terkandung didalamnya dikuasai oleh negara dan dipergunakan untuk sebesar-besarnya kemakmuran rakyat”.

Semakin meningkatnya kebutuhan akan tanah dalam segi pembangunan maka semakin terbatas pula persedian tanah, oleh karena itu harus dapat memanfaatkan tanah dengan optimal ${ }^{1}$. Pengertian Tanah terlantar terdapat dalam Pasal 1 angka 6 Peraturan Kepala Badan Pertanahan Nasional Republik Indonesia Nomor 4 Tahun 2010 tentang Tata Cara Penertiban Tanah Terlantar, yang dimaksud tanah terlantar adalah tanah yang sudah diberikan hak oleh negara berupa Hak milik, Hak guna usaha, Hak guna Pembanguna, Hak pakai dan Hak pengolaan, atau dasar penguasaan atas tanah yang tidak diusahakan, tidak dipergunakan,atau tidak dimanfaatkan sesuai dengan keadaannya atau sifat dan tujuan pemberian hak atau dasar penggunaannya. Jadi tanah terlantar adalah kondisi dimana para pemegang hak yang berhubungan dengan tanah yang bersangkutan tidak menggunakan, memanfaatkan, mengusahakan tanah tanggungannya.Hal tersebut tidak sesuai dengan Pasal 15 UUPA yang berbunyi "memelihara tanah, termasuk menambah kesuburannya serta mencegah kerusakannya adalah kewajiban tiap-tiap orang, badan hukum atau instansi yang mempunyai hubungan dengan tanah itu, dengan memperhatikan pihak yang ekonomis lemah", Pasal tersebut dengan jelas mewajibkan bagi yang memiliki hubungan hukum atau hak dengan tanah yang bersangkutan untuk merawat atau mempergunakannya bukan menelantarkannya.

Kenyataan yang terjadi pada Kasus yang pernah diselesaikan di Pengadilan Negeri Lhokseumawe adalah terhadap tanah kosong sebelum dibangun perumahan PT. Kereta Api merupakan tanah ulayat dari gampong yang sekarang masuk ke dalam wilayah gampong lancang garam yang peruntukannya adalah untuk keperluan dari masyarakat gampong lancang garam, sedangkan berdasarkan surat kepala kantor Pertanahan Kota Lhokseumawe tanggal 21 Januari 2011 Nomor 044/1311.73/I/2011pada angka 3 yang menyatakan bahwa; tanah yang dikuasai PT. KAI (Persero) bukanlah tanah negara bebas, tapi tanah negara yang telah ditetapkan undang-undang yang merupakan kekayaan Negara yang dikuasai pemerintah/BUMN

\footnotetext{
${ }^{1}$ Urip Santoso, Hukum agraria dan Hak-hak atas Tanah, Kencana,Jakarta, 2008, hlm. 2-3
} 
yang bersangkutan, tanah tersebut telah dikuasai PT. KAI (Persero) dan masih terdaftar dalam daftar asset milik PT. KAI.

Dalam kasus yang terjadi, penggugat telah memerintahkan kepada tergugat I untuk menghentikan proses penerbitan hak pengelolaan lahan (HPL) dan/atau Hak Guna Bangunan (HGB) terhadap objek sengketa serta menghindarkan diri dari tindakan yang melanggar hukum terhadap hak penggugat, selama belum ada keputusan mengenai pokok perkara, dan memerintahkan Tergugat II untuk menghentikan/mengakhiri perjanjian dengan Tergugat I karena objek perkara adalah miliknya penggugat.

Berdasarkan latar belakang kasus diatas maka penulis tertarik untuk menganalisis putusan dengan Nomor 03/Pdt.G/2011/PN-Lsm. Dan kemudian akan dituangkan dalam bentuk karya ilmiah Skripsi yang berjudul "analisis pertimbangan hakim dalam peralihan hak atas tanah terlantar Milik Badan Usaha Milik Negara Nomor : 03/Pdt.G/2011/PN-Lsm”.

\section{Metode penelitian}

Penelitian ini bersifat yuridis normative yakni penulis menggunakan metode pendekatan perundang-undangan (statute approach) dan pendekatan kasus (case apprach). Pendekatan perundang-undangan mengacu kepada undang-undang Nomor 5 Tahun 1960 tentang pokok-pokokAgraria, sedangkan pendekatan kasus (case apprach) adalah pendekatan yang dilakukan dengan cara menelaah suatu kasus yang telah menjadi putusan pengadilan berkekuatan hokum tetap, dalam hal ini yaitu Putusan Nomor 03/Pdt.g/2011/Pn-Lsm.

\section{HASIL PENELITAN DAN PEMBAHASAN}

\section{Posita}

Di dalam putusanPengadilan Negeri Lhokseumawe Nomor : 03/PDT.G/2011/PNLSM setelah membaca jawab menjawab antara kedua belah pihak yang berperkara, ternyata tergugat I dan tergugat III telah mengajukan eksepsi yang harus diberikan putusan terlebih dahulu sebelum melanjutkan pemeriksaan perkara ini, karena tergugat I telah mengajukan eksepsi tentang kompetensi absolut, sedangkan tergugat III mengajukan eksepsi tentang legal dari penggugat. Dalam eksepsinya tergugat I menyatakan bahwa gugatan penggugat jelas telah salah alamat karena diajukan ke Pengadilan Negeri Lhokseumawe (peradilan umum), karena Pengadilan Negeri Lhokseumawe tidak berwenang untuk memeriksa dan mengadili perkara sengketa Tata Usaha Negara, karena dasar kepemilikan hak atas tanah ini merupakan penerbitan dari surat/aturan hukum yang dikeluarkan oleh Keputusan Tata Usaha Negara, termasuk sengketa kepegawaian berdasarkan peraturan perundangan yang berlaku. Oleh karena itu gugatan yang diajukan oleh penggugat merupakan gugatan 
Tata Usaha Negara yang timbul akibat dikeluarkannya keputusan Tata Usaha Negara (dalam hal ini tentang kedudukan dan status kepemilikan asset/kekayaan negara yang dikuasai oleh PT. KAI (Persero). Dan sesuai dengan ketentuan yang berlaku, pengadilan Negeri Lhokseumawe haruslah menyatakan tidak berwenang untuk memeriksa dan mengadili perkara perdata Nomor : 03/Pdt.G/Pn.Lsm merupakan lingkup sengketa dalam wilayah hukum Peradilan Tata Usaha Negara (PTUN).

Penggugat dalam surat gugatannya menyatakan bahwa objek sengketa yang disebutkan dalam gugatannya adalah tanah negara, begitu pula halnya tergugat I dalam eksepsinya menyatakan tanah tersebut merupakan kekayaan negara yang dikuasai oleh PT. KAI. Berdasarkan Pasal 2, Pasal 3 ayat (1) dan Pasal 4 Peraturan Pemerintah Nomor 8 Tahun 1953 menentukan bahwa Menteri Dalam Negeri berhak menyerahkan penguasaan atas tanah negara kepada suatu Kementerian, jawatan atau daerah swatantra. Selanjutnya Pasal 23 huruf a angka 1 Peraturan Pemerintah Nomor 24 Tahun 1997menentukan bahwa penetapan pemberian hak dari Pejabat yang berwenang memberikan hak yang bersangkutan menurut ketentuan yang berlaku apabila pemberian hak tersebut berasal dari tanah negara atau tanah hak pengelolaan. Penggugat maupun tergugat I masing-masing mengklaim bahwa merekalah yang berhak untuk menguasai tanah negara tersebut. Maka yang menjadi titik sengketa adalah Keputusan Pejabat Tata Usaha Negara tentang siapa yang berhak untuk melakukan pengelolaan atas tanah negara tersebut. Yang berkaitan dengan eksepsi tergugat III mengenai Legal Standing dari penggugat dalam mengajukan gugatan ini akan dipertimbangkan sebagai berikut.

1. Berdasarkan Keputusan Walikota Lhokseumawe Nomor 272 Tahun 2008 tertanggal 06 Agustus 2008 telah mengangkat Muslim dalam hal ini penggugat sebagai Geuchik Gampong Lancang Garam Kecamatan Banda Sakti;

2. Berdasarkan Pasal 12 ayat (1) Qanun Provinsi Nanggroe Aceh Darussalam Nomor 5 tahun 2003 diantaranya menentukan bahwa tugas dan kewajiban Geuchik adalah mewakili gampongnya didalam dan diluar pengadilan dan berhak menunjuk kuasa hukum untuk mewakilinya;

3. Didalam surat gugatannya penggugat diantaranya menyebutkan bahwa Muslim AR, ST. Jabatan Geuchik Gampong Lancang Garam Kecamatan Banda Sakti Pemerintahan Kota Lhokseumawe bertindak untuk dan atas nama mewakili Pemerintah Republik Indonesia $\mathrm{Cq}$ Kementerian dalam Negeri Republik Indonesia $\mathrm{Cq}$ Pemerintah Provinsi Aceh $\mathrm{Cq}$ Pemerintah Kota Lhokseumawe Cq Kecamatan Banda Sakti Cq Gampong Lancang Garam;

4. Menurut Pasal 12 ayat (1) Qanun Provinsi Nanggroe Aceh Darussalam Nomor 5 tahun 2003 tersebut di atas menyatakan demikian, namun didalam 
menyebutkan bahwa Geuchik berhak mewakili gampongnya baik didalam maupun diluar pengadilan, namun didalam gugatannya penggugat lebih menonjolkan pribadinya daripada jabatannya sehingga bertentangan dengan Qanun seaabagaimana tersebut diatas, sehingga dengan demikian penggugat tidak mempunyai Legal Standing dalam mengajukan gugatan ini, maka dengan demikian eksepsi dari tergugat III Tentang Legal Standing dari penggugat dapat diterima.

\section{Pertimbangan Hakim}

Penggugat dalam surat gugatannya menyatakan bahwa objek sengketa yang disebutkan dalam gugatannya adalah tanah negara, begitu pula halnya tergugat I dalam eksepsinya menyatakan tanah tersebut merupakan kekayaan negara yang dikuasai oleh PT. KAI. Berdasarkan Pasal 2, Pasal 3 ayat (1) dan Pasal 4 Peraturan Pemerintah Nomor 8 Tahun 1953 menetukan bahwa Menteri Dalam Negeri berhak menyerahkan penguasaan atas tanah negara kepada suatu Kementerian, jawatan atau daerah swatantra. Selanjutnya Pasal 23 huruf a angka 1 Peraturan Pemerintah Nomor 24 Tahun 1997menentukan bahwa penetapan pemberian hak dari Pejabat yang berwenang memberikan hak yang bersangkutan menurut ketentuan yang berlaku apabila pemberian hak tersebut berasal dari tanah negara atau tanah hak pengelolaan. Penggugat maupun tergugat I masing-masing mengklaim bahwa merekalah yang berhak untuk menguasai tanah negara tersebut.

Bahwa tepatnya pada tanggal 28 Maret 2011 para penggugat dengan surat gugatannya yang telah ditolak dan di daftarkan di Kepaniteraan Pengadilan Negeri Lhokseumawe pada tanggal 30 Maret 2011 dengan Nomor 03/Pdt.G/2011/PN-Lsm. ${ }^{2}$

Bahwa penggugat mengatakan terhadap tanah kosong tersebut sebelum dibangun perumahan PT. Kereta Api merupakan tanah ulayat dari gampong yang sekarang masuk ke dalam wilayah gampong lancang garam yang peruntukannya adalah untuk keperluan dari masyarakat gampong lancang garam, sedangkan berdasarkan keterangan Kepala Kantor Pertanahan Kota Lhokseumawe dalam suratnya tertanggal 21 Januari 2011 Nomor 044/13-11.73/I/2011pada angka 3 yang menyatakan bahwa tanah yang dikuasai PT. KAI (Persero) bukanlah tanah negara bebas tapi tanah negara yang telah ditetapkan undang-undang yang merupakan kekayaan Negara yang dikuasai pemerintah/BUMNyang bersangkutan, tanah tersebut telah dikuasai PT. KAI (Persero) dan masih terdaftar dalam daftar asset milik PT. KAI (Persero), selanjutnya mengenai tanah yang dikuasai PT.KAI (Persero) bukanlah merupakan tanah ulayat dari Gampong Lancang Garam karena tanah tersebut tidak diusahakan oleh

\footnotetext{
${ }^{2}$ Ibid. hlm. 7
} 
masyarakat gampong tersebut. Sedangkan pengertian tanah ulayat menurut UndangUndang Pokok Agraria No. 5 tahun 1960 Pasal 3 menetukan bahwa :

"Dengan mengingat ketentuan-ketentuan dalam Pasal 1 dan 2 pelaksanaan hak ulayat menurut dan hak-hak yang serupa itu dari masyarakat-masyarakat hukum adat,sepanjang menurut kenyataannya masih ada, harus sedemikian rupa sehingga sesuai dengan kepentingan Nasional dan Negara, yang berdasarkan atas persatuan bangsa serta tidak boleh bertentangan dengan Undang-Undang dan peraturan lain yang lebih tinggi".

Dengan demikian penggugat telah memerintahkan kepada tergugat I untuk menghentikan proses penerbitan hak pengelolaan lahan (HPL) dan/atau Hak Guna Bangunan (HGB) terhadap objek sengketa serta menghindarkan diri dari tindakan yang melanggar hukum terhadap hak penggugat, selama belum ada keputusan mengenai pokok perkara, dan memerintahkan Tergugat II untuk menghentikan/mengakhiri perjanjian dengan Tergugat I karena objek terperkara adalah miliknya penggugat. Dalam pokok perkara karena Pengadilan Lhokseumawe tidak berwenang mengadili perkara ini dan penggugat tidak mempunyai Legal Standing mengajukan gugatan ini, maka gugatan penggugat harus dinyatakan tidak dapat diterima. Selanjutya hakim juga menolak seluruh gugatan penggugat dalam pertimbangannya hakim menilai bahwa Pengadilan Negeri Lhokseumawe tidak berwenang untuk memeriksa dan mengadili perkara Sengketa Tata Usaha Negara, yang timbul akibat dikeluarkannya Keputusan Tata Usaha Negara (dalam hal ini tentang kedudukan dan status kepemilikan aset/kekayaan negara yang dikuasai oleh PT. Kereta Api (Persero).

\section{Putusan Hakim}

Keputusan hakim dalam putusan Nomor:7/Pdt.G/2016/PN-Lsm menolak seluruh gugatan para penggugat yang menyatakan bahwa terhadap tanah yang menjadi sengketa tersebut merupakan tanah ulayat dari gampong yang sekarang masuk ke dalam wilayah Gampong Lancang Garam, yang peruntukannya adalah untuk keperluan dari masyarakat Gampong tergugat, hakim menilai bahwa hal tersebut tidak berdasar karena kepemilikan tanah oleh Tergugat I termasuk tanah yang menjadi objek sengketa adalah dilandasi atas Grondkaart yang berdasarkan Agrarische Wet(Staatsblad 1870 No. 55) dan Agraricshe Besluit (Staatsblad 1870 No. 118), Grondkaart merupakan gambar atau peta tanah yang dibuat untuk keperluan instansi pemerintah yang bersifat final sehingga tidak perlu ditindak lanjuti dengan surat keputusan pemberian hak oleh pemerintah.

\section{Kesimpulan}


Berdasarkan hasil analisis dan pembahasan diatas, maka dapat disimpulkanKonsepperalihan hak dalam putusan Nomor : 03/Pdt.G/2011/PnLsm).konsep peralihan hak atas tanah terlantar milik badan usaha milik negara membahas tentang konsep undang-undang dimana dalam keberadaan pasal-pasal dalam UUPA mengenai tanah terlantar belum dapat dilaksanakan sebelum adanya suatu peraturan operasional untuk menjalankan undang-undang sebagaimana mestinya, sehingga pemerintah mengeluarkan peraturan pemerintah Nomor 11 tahun 2010 yang menggantikan peraturan pemerintah Nomor 36 tahun 1998 tentang penertiban dan pendayagunaan tanah terlantar sebagai peraturan pelaksanaannya. 


\section{DAFTAR PUSTAKA}

Abdul Kadir Muhammad,2004,Hukum Acara Perdata Indonesia, Bandung, PT. Citra Aditya.

Adrian Sutedi,2007,PeralihanHakatas Tanah danPendaftarannya, Jakarta, SinarGrafika.

Andi Hamzah,2008,Asas-asasHukumPidana, RinekaCipta, Bandung.

Efendi Jonaedi, 2016, etalKamusIstilahHukumPopuler,CetakanPertama,Jakarta, Kencana.

Iman Sudiyat,1982,Beberapa Masalah Penguasaan Tanah di Berbagai Masyarakat Sedang Berkembang, Jakarta, Badan Pembinaan Hukum Nasional Departemen Kehakiman.

Kamil, Iskandar,2006, Kode Etik Profesi Hakim dalam Pedoman Perilaku Hakim (Code of Conduct), Jakarta, Mahkamah Agung RI.

Maria S.W. Soemardjono, 1998,Kewenangan Negara Untuk Mengatur Dalam Konsep Penguasaan Tanah Oleh Negara,Yogyakarta , UGM Press.

MuktiArto, 2004, Praktek Perkara Perdata pada Pengadilan Agama, CetV, Yogyakarta, Pustaka Pelajar.

Mukti Fajar dan Yulianto Ahmad, 2010, Dualisme Penelitian Hukum, Normatif dan Empiris, Yogyakarta, Pustaka Pelajar.

Notonagoro, 1984, Politik Hukum Dan Pembangunan Agraria Di Indonesia, Jakarta, PT. Bina Aksara.

Riduan Syahrani, Hukum Acara Perdata di Lingkungan Peradilan Umum, Cet I, Jakarta, Pustaka Kartini.

Soedikno Mertokusumo, 2002, Hukum Acara Perdata Indonesia, Yogyakarta, Liberty,

Soekanto Soerjono, 2012, Sosiologi Suatu Pengantar, Jakarta, Raja Grafindo Persada 